\title{
41資料 II
}

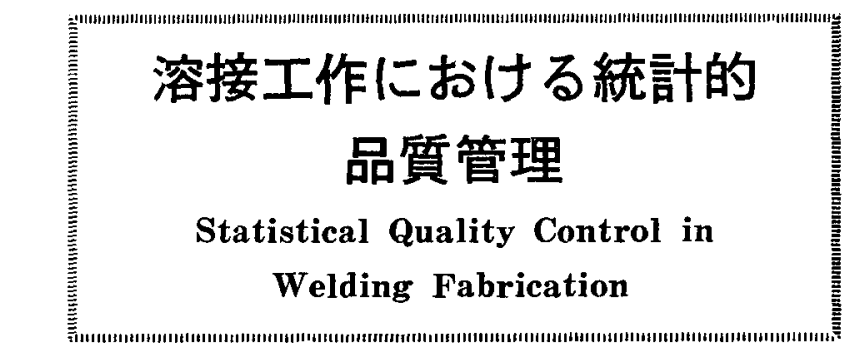

\section{統計的品質管理 の 理 論的考 察*}

\author{
田中守** \\ Theoretical study of Statistical Quality Control in \\ Welding Fabrication* \\ by Mamoru Tanaka**
}

\section{1 統計的品質管理を溶接搆造物の工作に導 入するための基本的考察}

\section{1 大量生産には歴史がある}

われわれは，大量生産に関する管理技法を，数多くも っているが, 溶接構造物の工作におけるような, 㑬別受 浩生産工場に適した，管理技法を，数多くはもっていな い.

前者は，今日の大量生産になるために，数多くの先人 達が苦労して，のこしていった研究のたまものなのであ る. 現在の大量生産む，むかしはわれわれの個別生産亡 おなじく，1個づつ製品をつくりあげていた，しかもヤ スリをつかってである，そういった状態のなかから今日 の大留生産になるまで，単に統計的品質管理だけが開発 されたのではない，生産システムむ，品質管理ととむ に，功ってているのである。このように考えるよ， 統計的品質管理があし導入されたとしても，ガタガタの 機械の電車1個だけを，精度のよいるのにかえたとおな じように，個別生産ではそれほど効果が上がるとは考え られない.

そこで，むう少し大量生産の歴史をふりかえって，そ の歴史のなかから，教訓をよみとるととにしよう。

大量生産というと，われわれがすぐ顕に浮か心゙るの

*原稿受付 昭和 13 年 6 月 12 日

**経賞コンサルタント Management Consultant
は，互换性のある部品をつかって，アツセンブリするよ うなラインである。

そのほか汇互換性を必要としない，単体をつくるむ のもあるが，ここでは溶接構造物が対象になるのだか ら，互換性を必要亡する，大㻎生産について述べるとと にしよう1).

1808年，英国の造船所で大舀の滑事を，海軍加受注 した.

滑東はすべての枠之，すべての滑車輪が，正碓におな じ寸法で仕上げられていて，どれかひとつの枠之滑車翰 とをあわせても，かならず合うようになっていなけれ ば，われわれが今日いっている“現場合わせ”という現 象を生ずる．このようなととを解決するために，はじめ て互换性という考えかたが導入された。そして機械を製 造工程の各段階に応じて，いくつかの群にわけたのであ る.

互換性は分業を促進したのである．乙のころは互換性 をうるために，上り精密な加工機械の発明を促したり， 上り精密な測定法の研究がすすんだ.

やがて互換性は，単にひとつの製品とか，企業だけで なく，いろいろな企業に必要な，ネジ，機械部品の規格 化ということを，おしすすめるでとになった。

さて分業化は，加工ロットとか運般ロットの概念を導 入し，工場内に扔ける部品の流机，譏械負荷のバラン ス，といった問題をクローズアップするととになる、ひ 
とつのととが解決すると，そのかげにかくされていた問 題が，あらわれてくるのである.

しかし，乙れらの問題を解決しなくては，女っかく互 換性を于化入れても，互换性の効果をまるまる手に入れ ることはできないのである。

しばらくのあいだ，乙の互换性をともなう大量生産方 式は，いろいろな製品に応用された。 大量需要の関係か ら，まず兵器製作にとり入れられ，時計，ミシンとつづ いた。 ミシンは1850年代であったが，そのころになる と，こういったタイプの大量生産方式はまったく確立

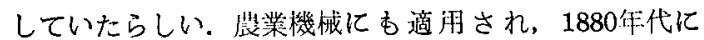
は，タイプライターに適用された。.1890年代になると自 転車に，そして，やがて1900㐿代になると，手う少し進 んだ大量生産方式になった。

自動車のアッセンブリラインに，コンぶアが登場して きたのである。

管理技術的な表現をすると，コンベアは，ロットの分 割を可能にした。

まえの工程からつぎの工程の作業域へ，製品が 1 個づ つ送られてくるのである. 加工とか運搬のロットを，考 える必要はない，てのように生産システムが移りかわる にしたがって，標準化とか，単純化，そして高門化への 道をますます歩くことになるのである。

フォードシステムでは, 製品の標準化, 部品の規格 化, 機械工具の專門化, 作業の標準化, そして工場の専 門化を計った。このようなシステムになると，互换性の 悪い部品があらわれると, コンベアラインでは, 細かく わかれた工程すべてに，手待ちを発生させることにな る. 品質に関する情報は，コンベアストップという非常 事態をとすなって，やってくるのである.

互換性㹥分業を生み，コンベけを導入したが，そうい った生産システムは，逆に品質レベルに対する要求を， きびしいものにした，すなわち，大最生産方式は，部品 の品質レベルがー定である，という条件のもとになりた っているのである. 大量生産方式は, 個別生産にある, 潜在的なアイドルを，生産ラインのなかから追放したの である。

合わないるのを合わせるのが，技術家の腕であると考 えて，個々ばらばらに製品をつくっていたのでは，との ような効果は，あらわれててないのである.

なお統計が，品質管理のための用具として，登場して くるのは，1920年代に入ってからであるが，そのことに ついては，あとで述べるととにしょう.

\section{2 統計的品質管理の導入にあたって考虑すべき こと}

大量生産の厢史にあらわれてきた問題は，つぎの2つ
にわけることができる.

その 1 互換性の問蝢

その 2 生産システムの問題

個別受泩生産においては，互換性といわ机るものがな い. そこで “互換性”というのは，それをつくりだす工 程にとって，どのような意味をもっているかを，考えて みるととにしよう。

部品に“互换性”をもたせるための寸法が与えられる と，この工程では，寸法どおりのおのをつくりだすよう 亿努力する，努力をする背景には，製造技術がある，乙 の製造技術を管理するてとによって，ある一永の品質し ベルを維持するのである.

製造技術というととになると，大量生産の工場はもち ろん，個別受注生産工場にもあることになる，製造技術 の無い工埸は考えることができない，

製造技術の管理といっても，品質管理では予防㑬な機 能を重視するから，古とでヤスリ掛けをしないであよい ように，寸法之精度とをある一定のレベルに保つのであ る.

てのように考えてくると，“北直し”とか“不良”は， 直接的に筒理の対象になるが，詥作については别の管理 が必要になる，むしろ ZD で取り扱う問題である。

予防的な意味で考えると，でき上った製品の寸法を， 個々別々に全部測定していたのでは意味がない，乙れ は，むしろ検查であって，製品ができ上る以前に，必要 な寸法がえられるようになっているととが望ましいので ある.

あう少し製造技術について述べておこう。

溶接構造物の工作というと，いろいろな刘象製品があ る. 造船，製䍊，車蟿，産業機械，鉄構等々である.

それぞれの工場では，アツセンブリを行なうとき，部

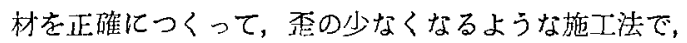
組立てを行なうところああ机ば，造船所のように“基準 線”をとおすようなアッセンブリあある．いずれにして 屯，最終们に構造物を，まとめるための技術なのであ る.

乙の技術は，物理的な条件之か，その工場の杯史的な 背景によって，それぞれ翼なっているはずである．個別 生原工場では，乙のような技術が，作業長以下の手に握 られていて，経験的に確立しているのがふつうである。 科学的に，経斎的にきめられたものではない．作業長以 下では，科学的，経济的佂拨術の確立を計る権限は，与 えられていないのがふつうである。

そこで，新工場のように物理的条件が変化すると，監 督のせいばかりでなく，経験们に定められた製造技術で は通用しなくなって，混㵇をおとす原因になる。 
もっと具体的な事柄を例にとろう.

たとえば，鋼板と鋼板とを，つき合わせ溶接しようと するとき，両方の板耳になる端面が，ぴったりくっつい ていて，隙間がない場合には溶接の条件だけで，縮みし ろはきまってくる，しかむ，条件さえおなじであれば， いつであおなじだけの縮みしろがあるということを知っ ている.

この知識は，一般に数式化された model で表現され る.物理学の text を開いてみると，一般化された mo・ del を発見するのは容易である.

たとえば，落体の法則の 1 つに,

$$
h=1 / 2 g t^{2}
$$

がある，物体が落下する高さを，重力と時間で示してい るあのである.

てのような model の世界のととを，われわれは pure science の世界であるといっている。

ところが，このような法則が成立つかどうかを，実験 しようということになると容易なととではない。

おそらく

$$
h \fallingdotseq 1 / 2 g t^{2}
$$

ということになるだろう。

溶接の縮みしろの場合でもおなじことである，理論式 はあっても，かならずしあ理論式ど打りにはならない． しかる実験室ではなくて，工場で行なわれるのであるか らなおさら理論式どおりにはならない.

しかも control すべき条件が工場によって異なって いる．それぞれの工場で設備屯異なれば，作業者も異な るし，施工法も異なるからである．工場でとに製造のた めの engineering が異なっているのは，あたりまえで あるといえる。

とのように考えてくると，製造技術というのは，pure sciehce がなりたつために，条件を設定させる技街であ るということができる．ところが工場であるから，製造 技術のもうひとつの面である，経済性ということが重要 になる。

経済的条件がなければ，いくらかでも条件をきびしく 設定することができる。しかし条件をきびしく設定すれ ばするほど，工作費はたかくつくし，その逆になると， 最終的な手直しが増加してくる.

溶接構造物では， assembly の途中で，板耳を切り なおしたり，溶接のビードを流してつけなおすととが多 い、いわゆる手直しである，経薺性というととから考え ると，手直しが悪くない埸合むある.

部材を突合せ溶接して，全体の長さが必要な長さにな るととが望ましいが，それでは，費用が高くなるとき に，外側の耳を切断して，求める長さをだすことああ
る.しかし品質管理では, 費用が高くならない施工法, 治具，工具，あるいはすっと工程の源流にさかのぼっ て，あとで行なう手直しをはぶく研究をする，てれが， shop floor における品質改善であって, 品質管理の重资 な分野である，予防機能を確立するととのために行なわ れるのである.

さて経済的に条件を設定するというが，設定の仕方お よび条件の維持ということが問題になる.

設定の仕方というのは，科学的でなくてはならない。

(1) assembly の基準はなにか.

(2) 各 stage ごとに基準からの虽差は，どれだけあ るのか.

(3) 基準からの誤差は, どれだけのコスト高になるの 加.

(4) 各工程の愦差のバランスをとるには，どのような 改善を行なうか。

(5) 基準の施工法が維持されるような管理システム を, design し実施する。

\section{2 製造技術と統計学について}

統計的品質管理について述べるのであるから，用具と しての統計について述べておてう。

\section{1 統計学の性格はなにか}

簡単なととばで表現すると群の性格をとり扱う学間で ある。

10円銅貨を投げ上げて，表がでるか裹がでるかを，予 测するととにしょう。

正確な科学的情報（たとえば，投げ上げた力，方向， 回転の速さ，風向き等々）が与えられないで, 結果をい いあてることは困難である．われわれが長いあいだ訓練 され教育されてきた，科学的といわれるものの考元かた は，適用することができなくなる，

表裹をいいあてるということについては，大人す子供 あまったくおなじである，ということができるだろう。 ただ大人になると，10円銅貨を何回も投げると，その回 数のうち，50\%は表で，50\%は裹がでるだろうといえ る.

前者は，個々の事象を問題にするが，後者は，何回も 繰り返えされた事象の集りを問題にするのである，すな わち完全な情報のもとでは，前者になるが，情報が不足 すると後者にならざるをえない，個々の事象ではなく て，いろいろ可能な条件のもとで発生する，事象の集り としての性格しかわからない，数学では群といい，維計 学では母集団という。

個々の事象でなく，群を問題にするのだから，群の性 格が研究されている．しかる日常われわれの工場にあら 
われてくる， popular な性格をすった群に対しては， 相当細かなところまで研究されているのである.

測定値の散らばりと，各測定值があらわれてくる頻度 とを，棒グラフで示すと，分布ができる．乙の分有が， 正䙺分布であったり，ポアッソン分布になると，それか らさきの分布の取报いかたは，完全に数学的とり扱いか たになるのである.

数学的之り扱いについては, あとで例がでてくるが, それよりあまえに，製造技術と統計学との関係を，あう 少し述べておく必望があるだろう。

\section{2 製造技術と統計学について}

製造技術というのは， pure science がなりたつため に，どれだけの条件を，満足させるかというこよであっ た.

図一1を例にとることにしよう。
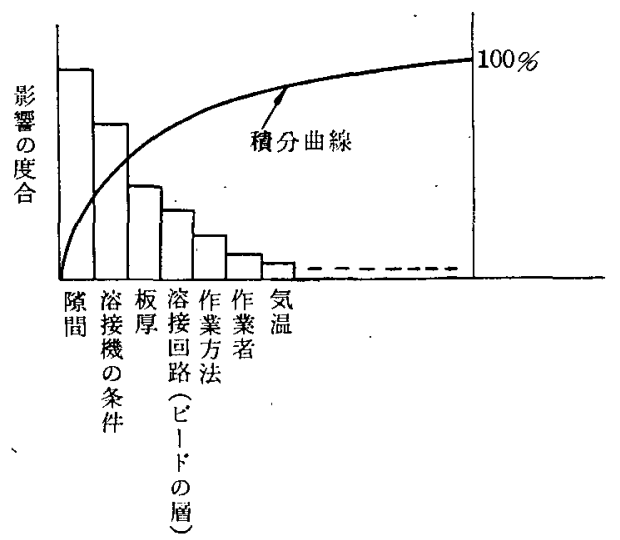

図-1

溶接の縮みしろを一䇥にするために，管理すべき項目 と，絔みしろに影栶を与える割合とが示されている，グ ラフに示されている内容は，実際にあったものではな い.グラフでは影響の度合が大きいものから，小さいむ のの順にかかれているむのよしよう．積分曲線はこれら 影響の度合いを䍗加していったすのである．品罂管理で は，てのようなグラフを“パレート図表”之称してい る.

さて，縮みしろを一方に保つために，積分岄絈で何\% まどを奖管理項目にするか，というととが engineering である：100\%を管理下におけばよいのだが，それは 2 つのととがらによって不呵能である.

第 1 K，乙の\%を大さくすればするほど，資用が增大 して、コマーシャル・ペースにのらなくなる。

第 2 に，物理的，化学的，精神的に，どうしても管理 下におくととができないるのがある、気温とか，作莱者
の心理による影響などについて out of control であ る.

この out of control の対象になる unknown factor が，縮みしろに対してある影響を与える，それは，大き くあらわれることもあるし，小さくあらわれるととああ る.

unknown factor の影響がどうあらわれるにというと とは，まえに述べた10内銅貨の表赛がどうあらわれる か，上いうの上まったくおなじであって，個々の事象に ついての科学的な悄報を欠如しているのである.

管理下にあるものは，条件を変えると，はっきり絬果 が変るけれど，乙の場合であ unknown factor が影響 して，揾った結果をくるわすことになる.

管理下におく factor が多ければ多いほど, unknown factor の影響が少なく，その逆であると影響が大きく なる。

さて，管理下におく factor の\%を一攸にしておい て，何回もおなじととを繰り这すと，unknown factor の影響が，大きくあらわれたり，小さくあらわ机たりし て, やがで影響する蝺囲を, 明らかれしてくる。
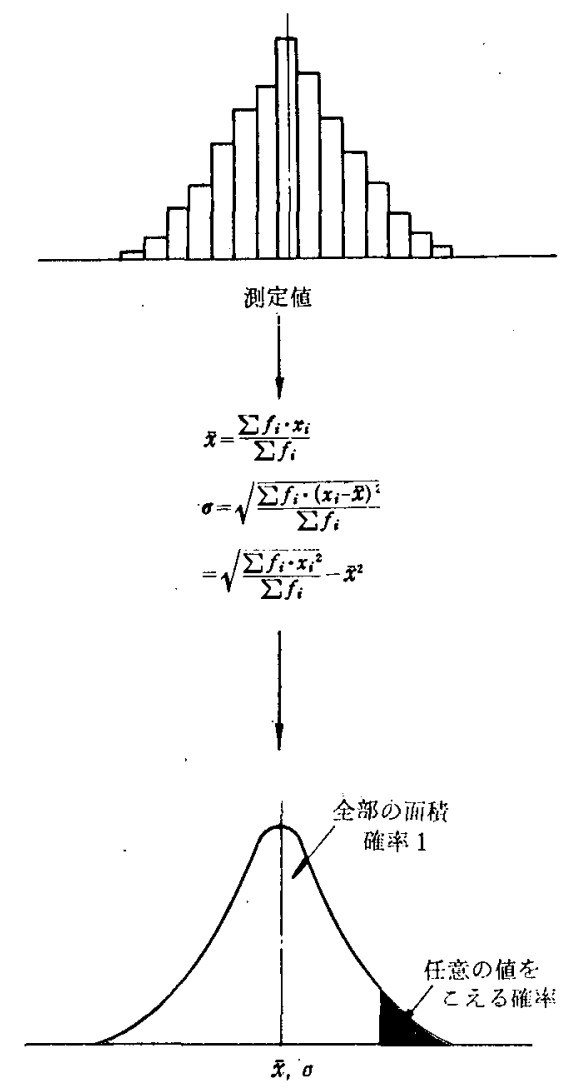

図-2 
すなわち，狙った樎みしろを中心に，縮みしろの量が 大きくあらかれたり，小さくあらわれるのである.

この分布の型が，正規分布になったり，その他の分布 になる.乙こまでくると統計学が，われわれに演繹的な 道をひらいてくれる. 狙った値が $\tilde{x}$ であり, 测定值の

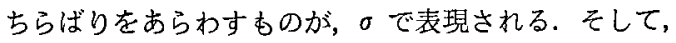
$\bar{x}$ 加 $\sigma$ を単位にして，いくら離机ていると，それ以 上の值がでてくる確率がいくらか，ということも容易に

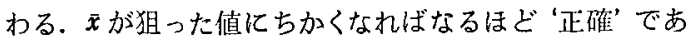
るという．また，ちらばり具合のことを精度”といった り “璪差”というのである。乙の世界には，原因と紹果と いう 1 対 1 の対応がない，あるのは‘平均”之‘ちらばり の籁囲”之，測定值が ‘範庰のなかに落ちる確率”だけ である.

\section{3 品質管理活動ट統計学について}

図一3は，軸受と軸との断面図である。

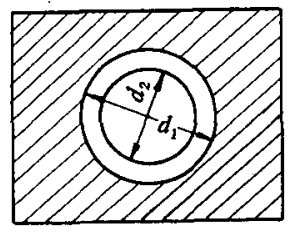

㢴-3

$$
\begin{array}{cc}
\text { 軸受の径 } & d_{1} \\
\text { 軸の径 } & d_{2} \\
\text { とすれば, } & \\
d_{1}-d_{2} &
\end{array}
$$

がきめられた寸法になれば，まえに述べた乎直し は，不必要である。

实際には，軸受の径がすべて $d_{1}$ になったり，軸の径 がすべて $d_{2}$ になるというととは，不可能であること を，述べてきた。

すなわち, unknown factoa があるからである.

ことわっておか私ばならないが，軸受の種類が 1 種類 であろうと，多種少量であろうと，それはかまわない， 1 種類である場合には，個々に $d_{1}$ を測定した值が，

$$
d_{1} \text { 土詿差 }
$$

になるが，多種少量の埸合は，

$$
\text { 測它值 }-d_{1} \text { (基準値) }= \pm \text { 土愦差 }
$$

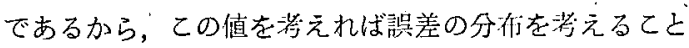
ができるのである. $d_{1}$ が大きいすのであろうと，小さ い屯のであろうと，絶刘值汃消元てしまうのである，す なわち，個別生産特有である，個々別々の管理という装 雑さから，われわれを救ってくれるのである．個别生産 であっても，統計学は大量生座におけると同様に，有效
な管理のための用具になるのである.

さて，話をもとにもどすことにしょう.

統計学では，2 うの正規分布の和，あるいは差の分布 はややはり正規分布になるとけう定理がある。

$$
1 \text { つの正規分布 ; } N_{1}\left(\mu_{1}, \sigma_{1}\right)
$$

他の正規分布， $N_{2}\left(\mu_{2}, \sigma_{2}\right)$

とすると, 求める正規分布は,

和の亡き

$$
N\left(\mu_{1}+\mu_{2}, \quad \sqrt{\sigma_{1}^{2}+\sigma_{2}^{2}}\right)
$$

差のとき

$$
\begin{aligned}
& N\left(\mu_{1}-\mu_{2}, \sqrt{{\sigma_{1}{ }^{2}+\sigma_{1}{ }^{2}}^{2}}\right. \\
& \text { ただし } \mu ; \text { 平均值 } \\
& \sigma \text {; 標準偏差 }
\end{aligned}
$$

以上の定理をつかって炎ええるととにしよう。

軸受扝よび軸 (複数)は, unknown factor の影響 でつぎのような值をとる.

$$
\begin{aligned}
& d_{1} \pm \sigma_{1} \\
& d_{2} \pm \sigma_{2}
\end{aligned}
$$

ここでは,クリアランスであるから, 隙間の小法はう ぎのようになる。

$$
\left(d_{1}-d_{2}\right) \pm \sqrt{\sigma_{1}^{2}+\sigma_{2}^{2}}
$$

この結果から, 各部品の寸法と, 組立てられたときの 必要寸法との関係がわかる.

しかもこの関係は, 軸の群扔よび軸受の群を対象にし ているのである．個々别々な製品であ执ば

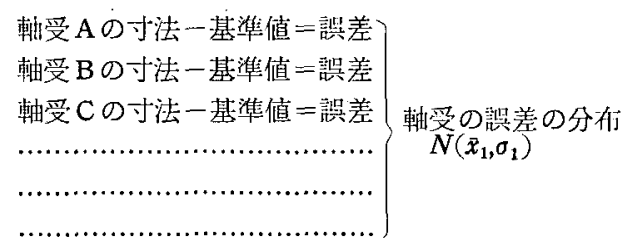

同様に，刺の場合は

$$
N\left(\bar{x}_{2}, \sigma_{2}\right)
$$

軸受と軸之のクリアランスは,

$$
N\left(\bar{x}_{1}-\bar{x}_{2}, \sqrt{{\sigma_{1}^{2}}^{2}+\sigma_{2}^{2}}\right)
$$

になるのである.

個々別々な管理は大変であるから，軸受および軸の゙あ る分類されれたすのについて，クリアランスの布をきめ るのである.

さて部品と組立ての関係は㹝ったが, 部品は部品で ある工程系列をとおってつくられる。

部品が，最終工程で手直しを受けないですむために は，この部品の工程が管理され格ばならない。

この場合にも，さきほどの定理が生かされる。

第1工程の影響は第 2 工程へ,ささらにつぎの工程に… ……影響を与えていく， 
たとえば，溶接工作物における鋼㤆の場合

現図の寸法誤差は，鋼板に睪畫かれる部材のかたちに 影響を与えるが，買書きには羁書きの誤差があって，現 図の誤差に付加さ机る.つぎの工程であるガス切断の場 合あおなじである.

そこで，各工程紤了時の基準寸法加らの誤差を求めた だけでは, 各工程個有の䛠差はわからない.

第 1 工程後の詥差 $\quad \sigma_{1}$

第 2 工程後の䛊差 $\sigma_{2}$

........

第 $n$ 工程後の卧差 $\sigma_{n}$ とすると，

第 $n$ 工程個有の誤差 $\sqrt{\sigma^{2}{ }_{n}-\sigma^{2}{ }_{n-1}}$

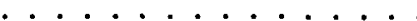

第 2 工程個有の誤差 $\sqrt{\sigma_{2}{ }^{2}-\sigma_{1}{ }^{2}}$

第 1 工程個有の誤差 $\quad \sigma_{1}$

で示される.

第 $n$ 工程の誤差という表現をしているが，一般にての 値を“工程の能力”といっている.

“工程能力研觉”には，いくつかの方法がある.

個々の測定值図表，ヒストグラム，管理図，その他の 統計的手法がある.

さて工程能力の研劣で, 各工程の精度を求めると, 仕 上りにおける部品の精度および正確さが，正しいかどう かがわかる.ここに述べている‘正しさ’というのは，最 終仕上り部品の寸法, 精度をうるために, 各工程での寸 法, 精度のバランスがとれているということである。 しどこかの工程でアンバランスが発生していると，ての 工程での品質改善が行なわれる.

図一 4 を例にとるととにしよう。

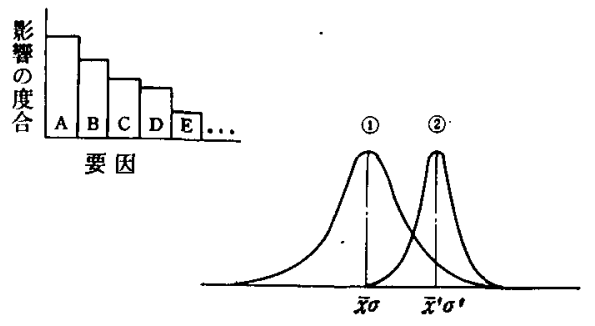

図-4

現在望因，A，B，C，D までか復理されているとき， この工程での寸法值が $\bar{x}$ で示され, unknown factor のために，精度が $\sigma$ であるとしよう。

xが正しい位置にあるかどうか.

$\sigma$ が必要な精度になるために，なにが管理されなくて はならないか。
すなわち，要因分析が行なわれるのである.

図一1のように要因がすべてにわたってわかっている ということは，現実の世界には少ない。

もし要因 E がわかり $\mathrm{E}$ を管理すると，てのヒスト グラムは(1)から(2)に変化して，求める值になる.

ヒストグラムの のの值は， unknown factor がどれ だけ少なくなるか，というととによってきまる，したが って，x の位置も正確に近くなってくるのである.

このように述べてくると，非常に簡単なようだが，い ま述べているのは，品質改善のプロセスについて簡善に 述べているのであって，実際はいろいろ困難なととがあ る.

贸区分析のための工場実験をするとき，おなじ条件で あっても，求める値は unknown factor のために，バ ラッキを生ずる. 工場実験であるから，つぎに条件（上

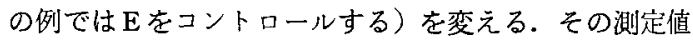
あ個々に見ると，みな異なっているのである.

前者の值が唯一で，後者の値もただ1つである場合 は，結果は簡単で前者，後者の差がはっきりする．しか も求めた测定値の個数（サンプル数）は，無限でなく有 限である.

\section{たとえば}

条件 A のときの測定值

$20,31,18,23,23,28,23,27,26,12,17$, 25,26

条件 B のときの测㫌值

$19,30,32,28,15,26,35,18,25,27,35$, ふつうはデーターを各100個ぐらい取って比較すると, 異 なっていることがわかる。

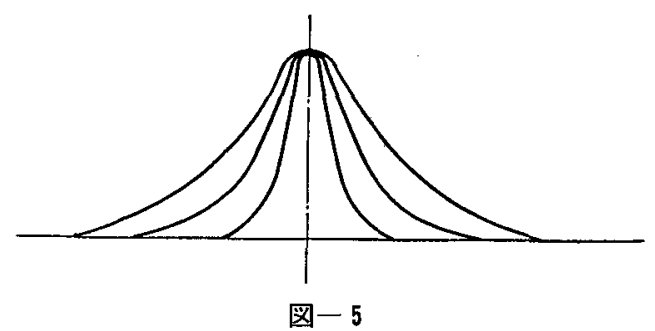

とてろが，上の例のように少数のサンプルを使って， 工程に影響を与える条件の度合を調べようとするとき， 個々の值を比較するだけではわからない．

こういったとき，統計学が有效な働きをする.

統計学では，まえに上げた例の属する分野のととを， 大鰾本淪といって，測延值が多くあった場合のときであ る.この分野は，数理統計学のなかで記述統計学とむい われる. 多数のサンプルを使って，分布関数を求めた りそうの理論を研究するのである。 


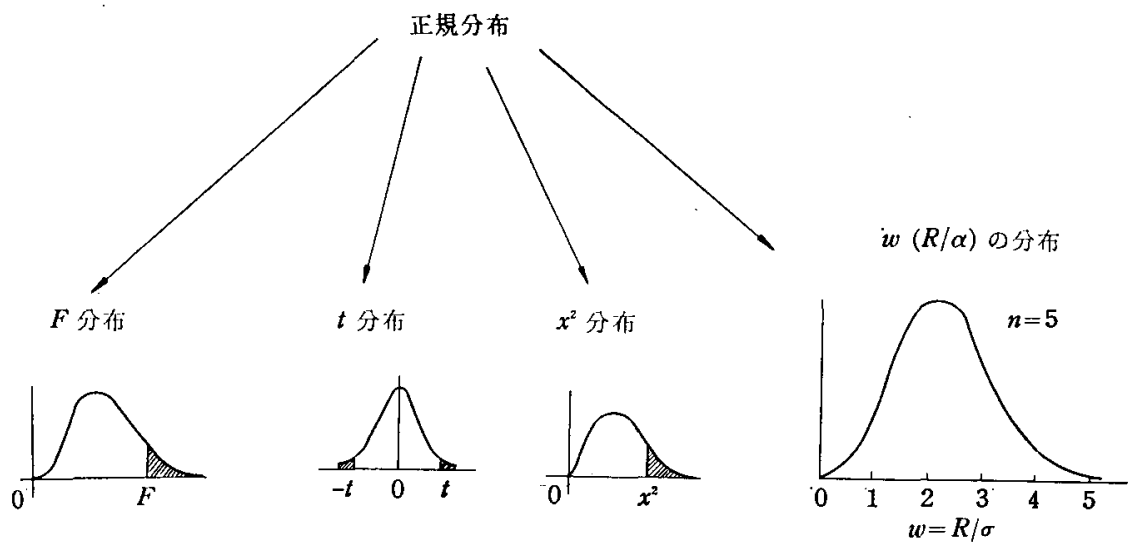

図一6

\section{図一 7}

(言葉の祱朋)

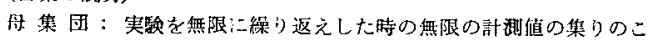
とである。

任意㬓本：Random に選び出した有限個の値であるあ. この個数のことを慓本の大きさという.

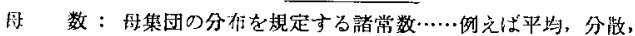
相閶係数……等者母数 (Parameter) といら.

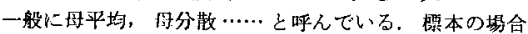
は，濆本平均，䅺本分散と称している。これは母数とは 本質的长異つたものである。

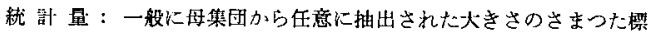
本の数量の閣数老統計量といい，母数之区斺する，一般 に統計量の分行を謤本分布といら。

期待值：統計的喥数の関数の期待值 (expected value) とは, その平均值のことである。

例えば，無限闪身団が正規分枌であるような群の中から 任意比選んだ票本平均の期待値といらのは，母集団の平 均值と同じである

これに対して，あとで述べた分野のととを，小標本論 というが，それは别に推測統計学，または推計学といわ れる分野であって，最近30〜40年ぐらいのあいだに，発 達した分野で，記述統計学のおよび得なかったてとを研 呪して, 近代数理統計学の主流をなしている.

この推計学というのは，ある分布 (母集间) から得ら れた小数のサンプルが, どのような分布をするか，とい うととから，母集団とサンプルのつくる標本分布との関 係を研究しているのである.

統計的品質管理が工場に持込まれたのは，1924年， Walter A. Shewhaat によるといわれているが，かれの 研究 “Economic Control of the Qualito of Manufactured Production” (1931年発行)は，もっ之以前に発 表された論文に剌激されたものである。1931年よりま え，ウエスタンホレクトリック社のホーソン工場にい た，ジュランに代表されるエンジニアたちが ‘最小の検 查結果から，最大の情報をうるととができる‘ととに大 きな関心をもった。
かれらの研究は，1929年 Bell System Technical Journal $飞$ “A Method of Sampling Inspection” $い$ う見出しで， Dodge と Roming によって発表されてい $る^{22}$.

getting the maximum amount of information from a minimum amount of inspection data.' ということは, 管理者によって, 注目すべきことがらで ある.

そこで，われわれは統計学の理諭にしたがって，サン プルから，母集団の母数（図一7参照）を推定したり, あるいは，うえの例の場合には，

条件を変えて行なわれたそれぞれの測定值が，捛なじ 母集団纪属しているかどうかを検定するのである. 測定 值之值とを，比較するのではなくて，測空值が属してい

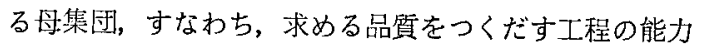
を此較しているのである.

さて, 品質改善は一般に工場寒験を行なうが，溶接構 造物の工作に関しては，最初そうむつかしい統計的手法 を使う必要はない，単に工程能力だけの調查をしても， 相当な効果が上るはずである。

\section{4 統計学は統制の用具になる.}

各工程の品質レベルがきまったならば，すなわち $\bar{x}$ とのがきまったならば，てれを維持しなくてはならな W.

このために統計がつかわれる，そのひとつに管理図が ある、管理図にっいては，あまりにあしれわたっている ので, ここでは割受することにしょう。

\section{3 統計的品質管理亡効果について}

統計的品質管理を導入しても，それだけでは効果がで ないということは，歴史の示すとてろである。 


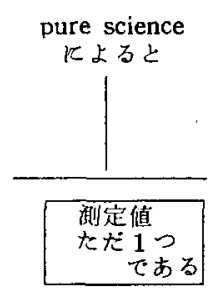

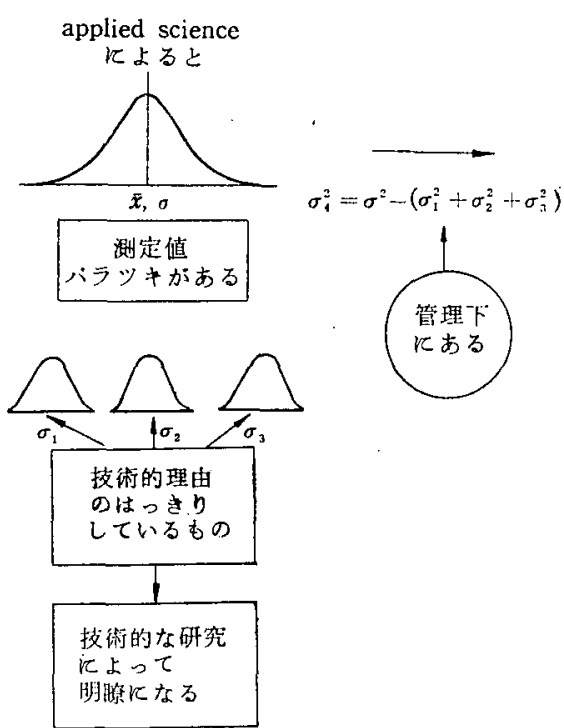

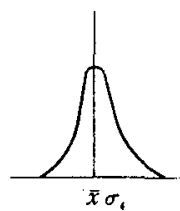

理由がはっきり しない原因に

よってバラッタ

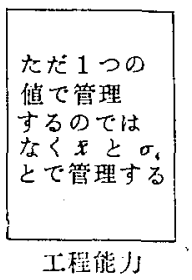

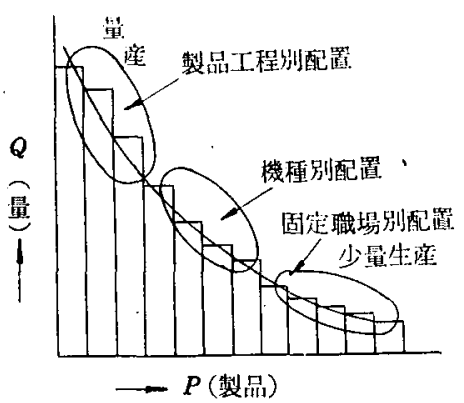

図一 9 生 程 態

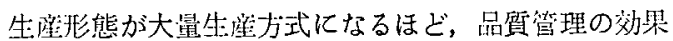
を発揮するし，また品質管理が大量生理方式を支えてい るといってすよいだろう，個別生澄の形態杜，乙の大量 生座方式にくらべると，はるか效率が悪い，

前者は，個々別々の製品を個々別々につくるのに対し て，後者は製品全体を効率よくつくろうとする，個々別 々な製品を，個々別々にっくっていたのでは，工場のな かにいろいるな手待ちが生じたり，行なわけなればなら ない仕事が，一時に発生することになる．大锤生搌方式 の1つであるコンベア作業では，各工程の俱荷のバラン スがとってある。るっと工場全体を考元ると，man， machine, material のあいだに統合されたシステムがあ る１つの工程を考元ると，与えられた作鄴畤間が経過 すると，つぎの材料が送り込まれてくる．作業者は与え られた場所と与えられた時間之，作業時間が一定になる ような品貿をむった忉渄で，作業を行なうのである。

図-8

品質だけ一定な材料がきても，俱荷のバランス，あの の流れ，あるいは他の工程と共用する汎用機械をつかっ て, 作業をすると，多くのアイドルをだして，品質管理 の效果がそれほどあらわれてとないのである，それでは

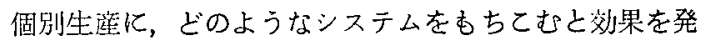
揮するのであるうか.

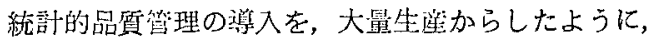
生潼システムも大貝生道の形態加ら発展させることにし よう3.

\section{1 流れ作業について}

図-10参照

$\boldsymbol{x}$ 軸；工程ナンバー

$y$ 軸；1個あたり作業封背

いま (1)工程に必望な製品 1 個あたりの扸工時間を $\bar{x}_{i}$ とすると，

$$
\bar{x}_{1}=\bar{x}_{2}=\cdots \cdots=\bar{x}_{i}=\cdots \cdots=\bar{x}_{n}
$$

とするととを，ラインバランスをとるという．

各工程の作業時間はバラックから，

バラッキを $\sigma_{i}$ とする.

各工程の作業時闑は

$$
\tilde{x}_{i} \pm 3 \sigma_{i}
$$

となる、

そこで，バラッキを吸収するために

$$
\frac{3 \sqrt{\sigma^{2}} \overline{i-1}+\overline{\sigma_{i}^{2}}}{\bar{x}_{i}}
$$

を求めて，端数を切り上げた整数個だけ，仕掛りをお くのである. 


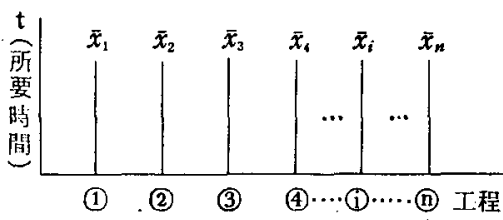

図一10 流

しかし，いつでる仕掛りが执けるとはかぎらない，特 に溶接構造物が大きくなったときである。仕掛りのため に，工場のほとんどがつかわ机るととになると，設備投 資の効率が昰くなる，仕措りがないものを“TACT system”といっている。元ちろんその他に，なるべく 同種の作業を同一工程に啭めるのである。乙れを質の分 業という，上に述へできたととは，量の分業である。

\section{2 汎用没備を共通に使う}

図一11参照

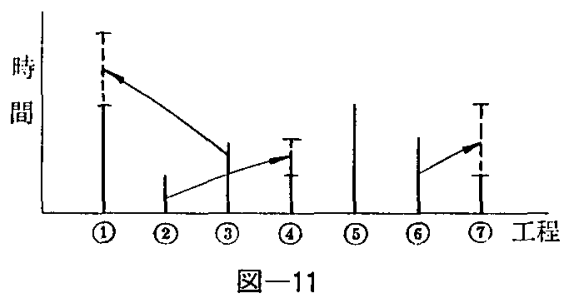

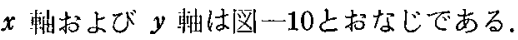

第(1)工程と第(3)工程はおなじクレーン

第(3)工程と第(4)工程はおなじ埸所

第(6工程と第(7)工程はおなじ加工機湘 としょう.

図一11のように矢印で示される位置に，それぞれの特 間をつけ吅えると，この工程系列を製品が 1 単位通過し たときに，

(1)には クレーン時間

(4)には おなじ場所が使用される時間

(7)にはおなじ加工譏械の使用時間

(1)，(2)，(3)，(4)，(5)，(6，(7)には各工程の時間が示さ れている。

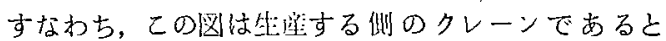
か，場所であるとかいったものの時間が示されている。

この図によると，(1)と(3)を処理するクレーン時間で， 製品 1 個ができるととになる，ただし作業埸所について は，ふつう工程の数だけ必要である，たとえば，作業が おわってクレーンをよぶと，作業時間にクレーン時間が

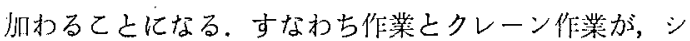

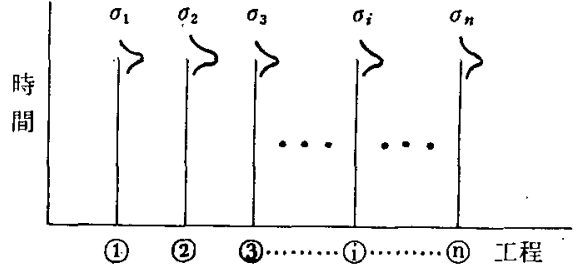

れ 作 業

リーズにつながることになる。作業とクレーン作業が， パラレルに行なわれるのであれば，作業がおわって製品 をおいておけることが必要である。

\section{3 コンペアはなくても TACT system の導入 は計かれる。}

コンベア作業は，人がうごかないで，製品がうごくの である。

逆に，人がうごいて製品が止まっていても，人と製品 上の相刘的関係はまったくおなじである.

図一12をみれば，人と場所との関係が，時間の経過に したがって変化している，場所は工程の数だけあればよ W.

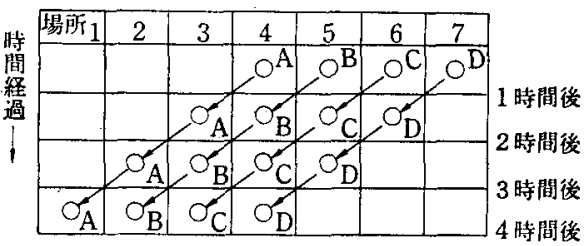

図-12

さてここであう少し桨察しておかね柿ならいのは， 場所が工程数だけない場合である。

溶接構造物の工作には，乙のような例が多い，組立て は扰なじ場所で行なっているから，工程の数之場所の数 についての考唖が，払われていないのがふつうである。 そういうときには工程数を娍らして，作業者を多能工化 するしかない，多能工というのは，上き場合によっては 必要だが，本来，分業から専門化という歴史的な過程か ら考えると，それほど効果のあるあのではない，かなら ず止むを得ない杀件がついて回っている.

\section{4 work unit をきめる}

流れ作業掞よびその底用について述べてきたが，それ で李 TACT system にはならない。极じ製品でない からである. そこで考えかたを変えて，各工程がおなじ 仕事量ならば, TACT system を導入するととができ るととに注目しよう。

製品でなく，製偘を組立てたりするとき，もつともべ 


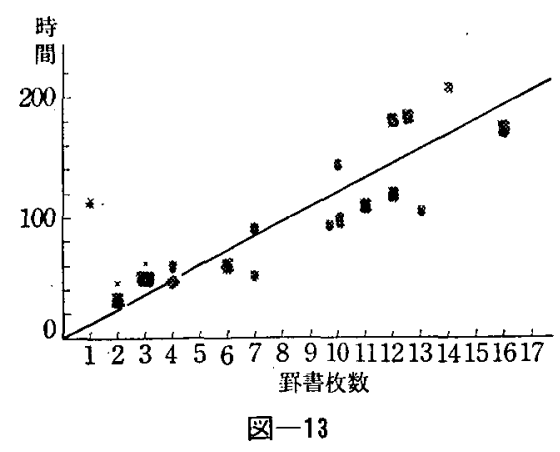

一スになる仕事の単位 (work unit)きめて, work unit をおなじだけ集める，という方法をとるのである.

鋼板の切断ならば，板の枚数之か， 1 枚の板に入って いるピースの数である. あるいは，同質の仕事で時間值 の異なるものを，ある標準值に換算するのである．换算 の仕方は，時間一物量のグラフにプロットして，回帰直
線からはずれるものに，ある一定の係数をかけて，回帰 直線上にプロットした点を移動するのである。

さて，そうやってる各工程の仕事最が，一定しないと きには，われわれがふっうやっている余力調整とか，あ る工事の日程的な先行という手をつかうのである. とあ かく，一定期間とか一定時間任程でとの作業がおわら なくては, system に狂いを生ずる。

生産システムは，一定の期間を中心に，いろいろな生 焦手段の歯車がかみ合ってまわっているてとに注目する 必要がある。

\section{文献}

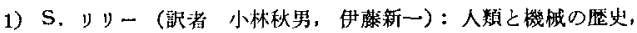
䇹波新書

2) Edited by Carl Heyel: The Encyclopedia of Manage ments, Reinhold Publishing Corporation

3) 田中 守：個别生産工昜の效率化，壁業能率短期大学，昭和42年

4) 田中守: IE $の$ 方法, 白桃畵房, 昭和 38 年

\title{
容接構造物の製作における精度管理の実際*
}

山本登**栗岡辰已**

\section{The Practice of Quality Control on Welding Construction*}

\author{
by Noboru Yamamoto** and Tatsumi Kurioka**
}

\section{1.まえがき}

一般に，工作機械，鉄道車蟿，造船といった業種は， 自動車, 䜬鎦などの業種にくらべて, 付加伍值生産性が 低い.

このちがいをいちがいに生应形態のちがいであるとい

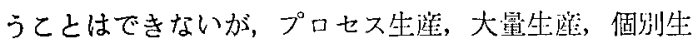
阵といった生産形態のパターンに分類してみると，その 形態の差が生産性の上に大きな影響を与えているてとが 明らかにされる。

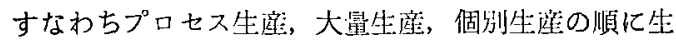
咸性が低くなっている。

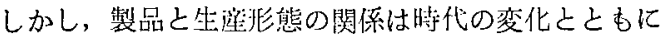

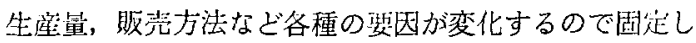
て結びっけるととはできない。

たとえば，業種別付加価值生啭性を時系列にしたがっ

* 原檍受付 昭和 43 年 5 月 28 日

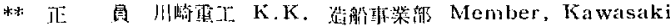
Dockyard Co. Ltd
てながめると，各澲種と屯生篗は增加しており，その增 加に対応するごとく個别生座は大量生禬にちかづき，大 量生産はプロセス生産の形態にちかづいている。そのよ うに時代の推移にともなって，その製品に対古る最適の 生糡形態は变化し得るものである。ゆえに，新しい時代 に適さなくなった生産形態は，むっと進んだ形態へと， 絶えず転換されなければならない，この転換のタイミン グが企業の生命を左不する。

最近管理技術の普及はぬざましいが，これらの普及の 理由が生産性を高めるためにあるととはいうまであな い，また，企業の体質改善しいう言葉がさかんに使われ ている、との言葉は生産工業では, 生産形態を変革する ことを密粕している。

しかし，乙れらの変革は，時代の流れにのって自然に 変䢬するという性格のものでなく，生産性向上をねらっ て技術革新的努力の槛み上げによって人為的に達成され るものである，このような要請から管理技術の発達が促 されたと解釈するとよもできる。

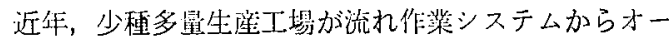

